\title{
Ferrous Sulfate
}

National Cancer Institute

\section{Source}

National Cancer Institute. Ferrous Sulfate. NCI Thesaurus. Code C29049.

A sulfate salt of mineral iron formulated for oral administration and used as a dietary supplement, ferrous sulfate is absorbed in the stomach and small intestine and combines with apoferritin to form ferritin, which is stored in the liver, spleen, red bone marrow, and intestinal mucosa. Important in transport of oxygen by hemoglobin to the tissues, iron is also found in myog lobin, transferrin, and ferritin, and is a component of many enzymes such as catalase, peroxidase, and cytochromes. 